\title{
Analysis of air pollution exposure in the area of lasi county - a warning signal for lung health and the risk of developing COPD
}

Ioana Buculei ${ }^{1, \#}$, Mona-Elisabeta Dobrin ${ }^{2,3}$, Anda Tesloianu², Cristina Vicol ${ }^{1, *, \#, ~ R a d u-A d r i a n ~ C r i s ̦ a n ~ D a b i j a 1 ~}{ }^{1}$, Sabina Antoniu ${ }^{1}$, Oana Elena Rohozneanu ${ }^{1, \#}$, Antigona Carmen Trofor ${ }^{1}$

"Pneumology Department, University of Medicine and Pharmacy „Grigore T. Popa” Iasi, Romania

${ }^{2}$ Clinical Hospital of Pulmonary Disaeses lasi, Romani

3Medical Science Department, University of Medicine and Pharmacy „luliu Hațieganu” Cluj-Napoca, Romania

Abstract

English:

Air pollution is a major threat to public health, and the effects of pollution are perceived in all countries of the world, by all social categories, regardless of age. Chronic obstructive pulmonary disease (COPD) has a growing prevalence worldwide and an increasing number of risk factors that exacerbate symptoms and accelerate disease progression. Exposure to air pollution is one of the less studied and less investigated risk factors for COPD. Depending on the size and chemical nature of the pollutant, it can overcome the defence mechanism of the respiratory system and enter the lung tissues, thus causing some respiratory diseases. The World Health Organisation (WHO) reports that six major air pollutants have been identified, namely particulate matter (PM), ground-level ozone, carbon monoxide, sulphur dioxide, nitrogen dioxide and lead. The severe impact of PM exposure is demonstrated by the link between exposure to high concentrations of PM and certain severe diseases such as silicosis, lung cancer, cardiovascular disease and COPD. In lași County, Romania, air quality measurements are performed by six automatic air quality monitoring stations, and the data obtained are used to create annual reports and these are also available online. Due to the high concentrations of air pollutants, the city of lași is one of the three topmost polluted cities in Romania. A future assessment on the impact of air pollution on the health of the inhabitants of these cities and the implementation of new methods to improve air quality is needed.

Keywords

air pollution $\cdot \mathrm{COPD} \cdot P M_{10}$

\section{Analiza expunerii la poluarea atmosferică în aria judetului lași - un semnal de alarmă pentru sănătatea plămânului și riscul dezvoltării BPOC}

Rezumat

Romanian:

Poluarea atmosferică reprezintă o amenințare majoră pentru sănătatea publică, iar efectele poluării sunt resimțite în toate țările lumii, de toate categoriile sociale, indiferent de vârstă. Bronhopneumopatia obstructivă cronică (BPOC) prezintă o prevalență în creștere la nivel mondial și un număr tot mai mare de factori declanșatori care exacerbează simptomele și accelerează progresia bolii. Expunerea la poluarea atmosferică este unul din factorii de risc ai BPOC mai puțin studiat și investigat. În functie de dimensiunea și natura chimică a poluantului, acesta poate depăși apărarea aparatului respirator și poate pătrunde în țesuturile pulmonare, determinând astfel unele afecțiuni respiratorii. Organizația Mondială a Sănătății (OMS) raportează șase poluanți majori ai aerului, respectiv pulberi în suspensie (PM), ozonul la nivelul solului, monoxidul de carbon, dioxizii de sulf, dioxizii de azot și plumbul. Impactul grav al expunerii la PM este demonstrat de legătura existentă între expunerea la concentrații ridicate de PM și unele boli grave precum silicoza, cancerul pulmonar, bolile cardiovasculare și bolile pulmonare obstructive cronice. La nivelul orașului lași monitorizarea calității aerului este realizată prin intermediul a șase stații automate de monitorizare a aerului, iar datele obținute sunt utilizate pentru crearea unor rapoarte anuale. Din cauza concentrațiilor crescute ale poluanților atmosferici, orașul lași face parte din primele 3 cele mai poluate orașe ale României. Se impune o evaluare viitoare a impactului pe care poluarea atmosferică îl are asupra sănătății locuitorilor acestor orașe și implementarea unor noi metode de îmbunătătire a calității aerului.

Cuvinte-cheie

poluare atmosferică $\cdot B P O C \cdot P M_{10}$

${ }^{*}$ Corresponding author: Cristina Vicol, Str. Dr. I. Cihac, nr. 30, Iaşi, Cod 700115, Romania.

E-mail: criss_mydoc@yahoo.com

"Ioana Buculei, Cristina Vicol and Oana Elena Rohozneanu are PhD students.

ว Open Access. ๑ 2021 Buculei et al., published by Sciendo

(c) Br-NC-ND This work is licensed under the Creative Commons Attribution-NonCommercial-NoDerivs 4.0 License. 


\section{Introduction}

The prevalence of chronic obstructive pulmonary disease (COPD) is increasing worldwide, with no known cure and a growing number of triggers that exacerbate symptoms and accelerate disease progression. Smoking is the main risk factor for COPD, and its role has been well characterised in the development, progression and exacerbation of COPD. However, it is not the only risk factor that should be considered. Exposure to air pollutants (both outdoor and indoor pollutants) is another important but lessinvestigated risk factor for COPD (1). The World Health Organisation (WHO) has estimated that in 2016, air pollution-in particular, exposure to suspended dust-was responsible for 4.2 million premature deaths worldwide; of these, $58 \%$ of premature deaths were caused by ischemic heart disease and stroke, $18 \%$ of deaths were caused by COPD and acute respiratory infections and $6 \%$ by lung cancer (2).

Worsening or acceleration of disease progression in relation to the level of pollution represents a research direction, with important implications in clinical practice. Following the analysis of the data obtained from the research done in the field, it will be possible to assess the need to apply measures to reduce pollution sources in urban areas.

\section{Pollution and COPD}

It is known that the environment influences human health. The influence of exposure to air pollutants on human wellbeing and health has been an interesting and intensely studied topic. Exposure to air pollution is considered to be one of the major factors leading to multiple diseases, such as cardiovascular disease and lung disease (3).

In 1999, WHO defined air pollution as 'substances deposited by human activities in sufficient concentration to cause harmful influences on health, vegetation, crop yields, property or to interfere with property welfare' (2). Natural or artificial substances that pollute the environment are called pollutants (4). Air pollution can also be defined as a destructive effect of any source that contributes to air pollution and/or environmental damage $(3,5)$.

Assessing human exposure to air pollution is a fundamental part of the more general health-risk-assessment process, by which the increase in the risk to human health caused by exposure to air pollutants can be estimated (6).

Exposure to air pollution can be assessed by direct or indirect methods. Direct methods involve measuring personal exposure, either by sampling or by measuring biological markers. Indirect methods involve the calculation of human exposure, through a combination of concentrations in different locations and the time spent by humans in each specific environment, encompassing both the indoor and the outdoor environment $(3,6)$.

Air pollution has become a major global threat to human health. Historically, several major episodes of air pollution worldwide in the early twentieth century have caused severe adverse health effects. Most tragically, the 'killer fog' in London in 1952 caused 12,000 unexplained deaths and serious longterm effects on human health (7). In 2012, indoor and outdoor air pollution caused 6.5 million deaths, covering $11.6 \%$ of the total deaths globally (8).

On account of the impact of human activities on the environment, the interaction between humans and the environment has been widely studied. The environment is the space in which we carry out all our activities; it includes soil, air, water, living organisms and microorganisms, as well as all the relationships that ensure a balance between all these elements (9).

Thus, pollution is defined as the introduction into the environment of substances harmful to humans and other living organisms and is the process of changing the natural characteristics of the atmosphere due to the effects of the chemical, physical or biological agents that harm the environment. Pollutants are solids, liquids or gases produced in higher-than-usual concentrations, which reduce the quality of the environment (2).

Pollution can be of a physical nature (thermal pollution - steam discharge, hot water; noise pollution), chemical nature (pollutant discharge - over 20.000), biological nature (pathogens from animal manure and food residues) and radioactive nature (radioactive isotopes - Cs-137, Cs-144, Sr-90, Ba-140, I-131, U-238, Zr-95 etc.). In addition, pollution can be simple, i.e. caused by a single pollutant, or complex, i.e. encountered in industrial and urban areas with heavy vehicle traffic.

The sources of air pollution can be classified according to their origin into natural and artificial sources. Eighty per cent of air pollution is produced by large-scale human activities, such as the use of industrial machinery, power stations, combustion engines and machinery. There are other human activities with a smaller influence on the environment, such as farm cultivation techniques, the use of fuel tank heaters and cleaning procedures, and many natural sources, such as volcanic eruptions and forest residues (9).

COPD is defined by the 2020 Global Initiative for Chronic Obstructive Lung Disease (GOLD) guideline as 'a chronic, preventable and treatable disease, characterized by persistent respiratory symptoms and limited airflow, caused by abnormalities of the airways and/or alveoli, most often caused by significant exposure to harmful particles or gases' (10). 
Studies on the role of pollution in the development of COPD have shown its negative impact on both lung function and exacerbations of the disease. Outdoor pollution is the trigger for acute exacerbations of COPD, increased intensity of symptoms, addressability in emergency units, the number of hospitalisations and even mortality (11). This was confirmed by a meta-analysis conducted by Jinhui $\mathrm{Li}$ et al., which included 59 studies on the association between short-term exposure to air pollutants and COPD exacerbations. The results showed a significant association between shortterm exposure to gaseous and particulate pollutants and COPD exacerbation risk. The authors of the meta-analysis concluded that controlling outdoor air pollution is important for COPD patients because short-term exposure increases the risk of COPD acute exacerbations significantly (12).

It was estimated that $20 \%$ of COPD cases worldwide occur due to exposure to such pollutants (13). A study conducted by Hendrix et al. about the risk of incident COPD and asthma owing to exposure to air pollution (in which women from three age cohorts were included and followed for 20 years) showed that adult women without baseline COPD were at higher risk of developing COPD when they lived in areas with high concentrations of air pollutants resulting from multiple sources. This study also showed that the risk of developing COPD was inversely proportional to the distance between the emitting sources and the women's residence (14).

WHO reports six major air pollutants, namely dust pollution (Particulate Matter [PM]), ground-level ozone, carbon monoxide, sulfur oxides, nitrogen oxides and lead.

\section{Particulate matter}

PM is usually formed in the atmosphere as a result of chemical reactions between various pollutants and includes particles with a diameter of $10 \mu \mathrm{m}$ or less, called $\mathrm{PM}_{10}$, and extremely fine particles with diameters that are generally $2.5 \mu \mathrm{m}$ and smaller, called $\mathrm{PM}_{2.5}$ (15). PM contains small drops of liquid or solid substances that can be inhaled, which can cause serious adverse health effects. Particles less than $10 \mu \mathrm{m}$ in diameter can enter the lungs by inhalation and can even reach the bloodstream. Fine particles, $\mathrm{PM}_{2.5}$, pose a higher health-risk. The degree of penetration of the particles in the respiratory system depends on the size; PM with a diameter greater than $11 \mu \mathrm{m}$ penetrates the nostrils and can reach the upper respiratory tract, and PM with a diameter of less than $0.43-0.65 \mu \mathrm{m}$ reaches the alveolar level (9).

An association of materials from artificial and natural sources forms the primary and secondary particles that are included in PM. They are composed mainly of organic compounds (polycyclic aromatic hydrocarbons), minerals (water-soluble ions), metals and biogenic elements. Various factors such as weather conditions and emission sources can influence the physical and chemical properties of PM. These particles can be dispersed directly from natural sources such as fires or can be produced by gas-particle conversion processes. The anthropogenic sources of PM in urban areas are mainly represented by cars through the exhaust gases containing $\mathrm{CO}$, polycyclic aromatic hydrocarbons, $\mathrm{SO}_{2}, \mathrm{NO}_{x}$, volatile organic compounds, soot, asbestos etc. (16). The fuel used and its composition, and also the technology used to build the engines of automobiles, have an impact on the concentration of pollutants released into the air (17).

The serious impact of the exposure to PM is shown by the link existing between exposure to high levels of PM and conditions such as silicosis, lung cancer, cardiovascular disease and COPD (18).

Lingyan Yang et al. studied the association between the development of COPD and PM 2.5 components and showed that organic pollutants, such as polycyclic aromatic hydrocarbons (PAHs) and biphenyl polychlorides (PCBs), are major risk factors. The mechanism is the disruption of the epithelial lung barrier by depleting proteins in the occluded area. At the same time, there is an increase in oxidative stress, which leads to DNA damage, increased production of proinflammatory cytokines and decreased expression of $\alpha 1$-antitrypsin (19).

In a systematic review and meta-analyses, Bloemsma et al. included 25 panel studies that were published between 1993 and February 2016. This systematic review aimed to assess the evidence existing on the acute effect of air pollution among patients with COPD. Evidence from the identified panel studies indicated statistically significant associations of PM air pollution with lung function impairment in patients with COPD (20).

A time-series study conducted in Shanghai, China, by Ying et al. explored the existentrelationship between size-fractionated particle number concentrations and COPD mortality. The data obtained in the study suggested that particles below $0.3 \mu \mathrm{m}$ in diameter might be mainly responsible for the adverse effects of particulate air pollution on COPD mortality in Shanghai, China (21). Lu et al. in 2015 also suggested in a systematic review and meta-analyses that short exposure to $\mathrm{PM}_{10}$ and $\mathrm{PM}_{2.5}$ is significantly associated with increased mortality (22).

Data from literature show that exposure to environmental air pollutants exacerbates respiratory illnesses, which can be a risk factor and also can have an impact on the mortality of this type of disease. More studies regarding the impact of exposure to air pollution on the development and evolution of respiratory disease should be conducted in the future.

\section{Pollution in lași County, Romania}

Romania's Air Pollutants/Air Quality Monitoring Network consists of 142 automatic air quality monitoring stations. 
In lași County, the monitorisation of the air quality is done by an automatic air quality monitoring network consisting of six automatic monitoring stations, equipped with highperformance analysers that apply the reference methods. This network was built in 2005 through the PHARE RO 2002 Project 'Improvement of the national air quality monitoring network' and consists of IS-1 station, IS-2 station, IS-3 station, IS-4 station, IS- 5 station and IS-6 station. These six stations are located both in urban and in rural areas and are divided into traffic stations, urban background stations, industrial type stations, rural background stations, suburban background stations and urban-traffic background stations. They monitor the concentration of certain air pollutants. All stations have a 24 hours monitoring program that provides an hourly average of the key air pollutants.

IS-1 station- traffic station, is located in a residential area of lași and monitors the influence of traffic on air quality to highlight the level of pollution to which the population of Iași is exposed. This station monitors pollutants such as $\mathrm{SO}_{2}, \mathrm{NO}$, $\mathrm{NO}_{2}, \mathrm{NO}_{\mathrm{x}}, \mathrm{CO}$, automatic and gravimetric $\mathrm{PM}_{10}, \mathrm{~Pb}, \mathrm{Cd}, \mathrm{Ni}$ (from $\mathrm{PM}_{10}$ ), benzene, toluene, o-xylene, ethylbenzene and $m, p$-xylene (online).

IS-2 station- urban background station, is located inside a nursery and monitors the level of pollution in urban areas and the influence of 'human settlements', without being directly influenced by traffic or industry. This location was chosen for the station to ensure that the monitored pollution level is influenced by the integrated contributions arising from all sources, such as the opposite direction of the wind and the open spaces in residential and commercial areas including educational facilities. Among the pollutants monitored are included the following, namely: $\mathrm{SO}_{2}, \mathrm{NO}, \mathrm{NO}_{2}, \mathrm{NO}_{x}, \mathrm{O}_{3}, \mathrm{PM}_{10}$ gravimetric, $\mathrm{PM}_{2.5}$ gravimetric, benzene, toluene, o-xylene, ethylbenzene, $m, p$-xylene (online) and meteorological parameters (direction and wind speed, temperature, pressure, solar radiation, relative humidity and precipitation). IS-3 station- industrial type station, monitors air quality in a residential area that is under the influence of emissions from one or more industrial areas. This station automatically monitors the following pollutants, namely: $\mathrm{SO}_{2}, \mathrm{NO}, \mathrm{NO}_{2}, \mathrm{NO}_{x}$ and $\mathrm{PM}_{10}$.

IS-4 station- rural background station, is located in a village near lași at a far distance from pollution sources. This station monitors the level of pollution that is not influenced by traffic congestion or the industrial area in its vicinity. Monitored pollutants are $\mathrm{SO}_{2}, \mathrm{NO}, \mathrm{NO}_{2}, \mathrm{NO}_{x}, \mathrm{CO}, \mathrm{O}_{3}, \mathrm{~Pb}$ (from $\mathrm{PM}_{10}$ ), $\mathrm{Cd}$ (from $\mathrm{PM}_{10}$ ), $\mathrm{Ni}$ (from $\mathrm{PM}_{10}$ ) and $\mathrm{PM}_{10}$ gravimetric meteorological parameters (such as wind direction and speed, temperature, pressure, solar radiation, relative humidity, precipitation).

IS-5 station- suburban station, located inside a school in Tomești village, in the dominant direction of the wind, monitors pollution levels resulting from the transportation of pollutants outside of lași, without being directly influenced by emissions from traffic or industry. This station provides information on the exposure of the population and vegetation in the vicinity of lași to high ozone levels. Monitored pollutants are $\mathrm{SO}_{2}, \mathrm{NO}, \mathrm{NO}_{2}, \mathrm{NO}_{x}, \mathrm{CO}, \mathrm{O}_{3}$, gravimetric $\mathrm{PM}_{10}, \mathrm{~Pb}$ (from $\mathrm{PM}_{10}$ ) and $\mathrm{BTX}$.

IS-6 station- urban-traffic background station, located at the border between Romania and the Republic of Moldova. It is used to monitor air quality at the border where air quality is assessed only based on emissions from Romanian sources and air quality is affected by exceeding thresholds for $\mathrm{NO}_{x}$ and $\mathrm{PM}_{10}$ pollutants. According to the legislation, in such a situation it becomes mandatory to continuously measure the concentration of pollutants in fixed points. Monitored pollutants are $\mathrm{SO}_{2}, \mathrm{NO}, \mathrm{NO}_{2}, \mathrm{NO}_{x}, \mathrm{~Pb}$ (from $\mathrm{PM}_{10}$ ), automatic and gravimetric $\mathrm{PM}_{10}, \mathrm{CO}$, benzene, toluene, o-xylene, ethylbenzene, $m, p$-xylene (online) and meteorological parameters (direction and speed of wind, temperature, pressure, solar radiation, relative humidity and precipitation) (23).

Such automatic air quality monitoring stations are found all over the world and they are used as indirect methods for the determination of the population's exposure to certain air pollutants.

The information regarding air pollution and the air quality recorded by these stations is made available to the residents of lași County and the public through two information panels. One of these panels is located outside the Agency for Environmental Protection in lași and provides information on air quality in the form of daily average values, and the other panel is located inside the Agency and provides information in the form of average hourly values.

The data registered by these stations can be accessed directly on the following websites: www.calitateaer.ro and https:// aqicn.org/map/romania/. On these sites, the data recorded for days and hours can be accessed, and also, reports on the concentration of a particular pollutant can be downloaded. Air quality is represented in the form of six indexes. Table 1 shows these indexes for the PM with a diameter less than or equal to $10 \mu \mathrm{m}$. This is a general air quality index and it is a tool used to communicate the air quality to the public; it allows the periodic description, in a simple form, of the information on the overall air quality status in the area of each automatic air quality monitoring station by hourly display on both exterior and interior panels, as well as on the website www.calitateaer.ro.

The measured concentration of $\mathrm{PM}_{10}$ is in direct correlation with the source, with the humidity (due to the agglomeration of particles) and with the wind speed that determines the resuspension of the soil and the transport to long distances from the source. The maximum daily concentrations of $\mathrm{PM}_{10}$ are directly influenced by weather factors - wind direction 
Table 1. The specific index corresponding to $\mathrm{PM}_{10}$.

\begin{tabular}{lc}
\hline Air quality index & $\mathrm{PM}_{10}$ value $\left(\mu \mathrm{g} / \mathrm{m}^{3}\right)$ \\
\hline 1 & $0-20$ \\
2 & $20-40$ \\
3 & $40-50$ \\
4 & $50-100$ \\
5 & $100-150$ \\
6 & $150-1200$ \\
\hline
\end{tabular}

and speed, precipitation, air temperature etc.--and also with the geographical factors specific to the area.

According to the Romanian law No.104 of 15th June 2011 on the permitted limit values for certain air pollutants, the daily limit for the protection of human health in the case of $\mathrm{PM}_{10}$ is $50 \mu \mathrm{g} / \mathrm{m}^{3}$, which should not be exceeded more than 35 times/ year and the annual limit for the protection of human health for the same air pollutant is $40 \mu \mathrm{g} / \mathrm{m}^{3}$ (24).

According to the European Environment Agency, in 2017, in lași County, the $\mathrm{PM}_{10}$ concentrations registered in the urban environment exceeded the maximum allowed limit, having a value of $72.23 \mu \mathrm{g} / \mathrm{m}^{3}$. The concentrations registered in rural areas also exceeded the limit but not at the same level, having a value of $38.94 \mu \mathrm{g} / \mathrm{m}^{3}$ (25).

Figure 1 represents the average concentration of PM with a diameter less than or equal to $10 \mu \mathrm{m}$ concentrations in the city of lași in October 2020; this concentration-data was calculated from the daily data recorded by IS-1, IS-2, IS-4, IS-5 and IS-6 stations. IS-2 station is an urban background station that monitors the pollution which is not influenced by traffic, being a station located inside a nursery.
Figure 2 shows the daily $\mathrm{PM}_{10}$ concentrations in the city of lași in October 2020 that were recorded by IS-2's urban background station, which is located inside a nursery and monitors the level of pollution in urban areas and the influence of 'human settlements' without being directly influenced by traffic or industry.

In Figure 3, the annual $\mathrm{PM}_{10}$ concentrations recorded by the station in lași, Romania, are represented.

According to the annual air quality reports made by the National Agency for Environmental Protection (ANPM) in Romania, in 2019, there were no exceedances in the annual limit value $\left(40 \mu \mathrm{g} / \mathrm{m}^{3}\right)$ for $\mathrm{PM}_{10}$ at any station from among the number of stations considered in this report, but there were exceedances of the daily limit value at 54 stations, at 5 stations there were more than 35 exceedances (2 of these stations are located in lași), 54 exceedances at IS-1 (traffic station) and 36 exceedances at IS-2 lași (urban background station) (26).

In 2018, there were exceedances observed of the annual limit value $\left(40 \mu \mathrm{g} / \mathrm{m}^{3}\right)$ at two stations from the number of stations considered in the ANPM 2018 report: IS-1, traffic station $\left(45.02 \mu \mathrm{g} / \mathrm{m}^{3}\right)$ and IS-6, urban background stations (42.42 $\mu \mathrm{g} /$ $\mathrm{m}^{3}$ ). At the same time, there were exceedances of the daily limit values more than 35 times in a calendar year at 6 stations ( 3 of them located in lași), 105 exceedances at IS-1 (traffic station), 60 overtaking at IS-2 lași (urban background station) and 83 overtaking at IS-6 (urban traffic background station) (27).

In 2017, there were exceedances of the annual limit value $\left(40 \mathrm{\mu g} / \mathrm{m}^{3}\right)$ at one station from the number of stations considered in the report made by ANPM and IS-1 station (traffic station) located in lași, respectively. Regarding the

\section{$\mathrm{PM}_{10}$ Concentrations}

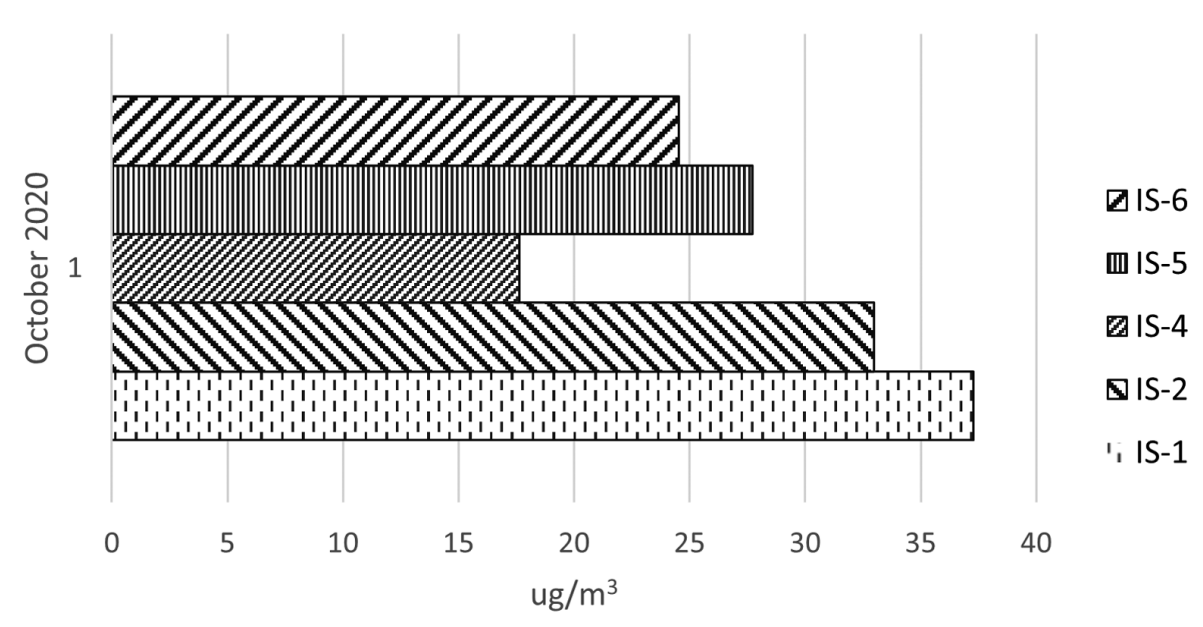

Figure 1. Monthly $\mathrm{PM}_{10}$ concentrations in the city of lași in October 2020. 


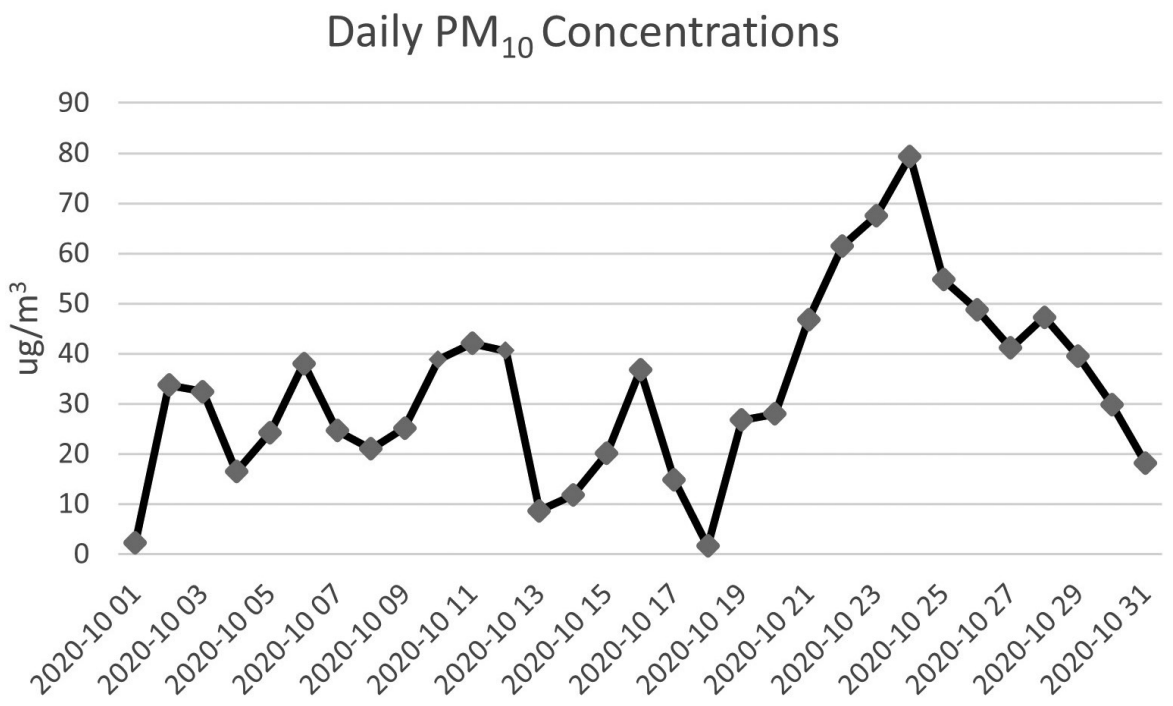

Figure 2. Daily $\mathrm{PM}_{10}$ concentrations in the city of lași in October 2020 - IS-2 station.

\section{$\mathrm{PM}_{10}$ Concentration}

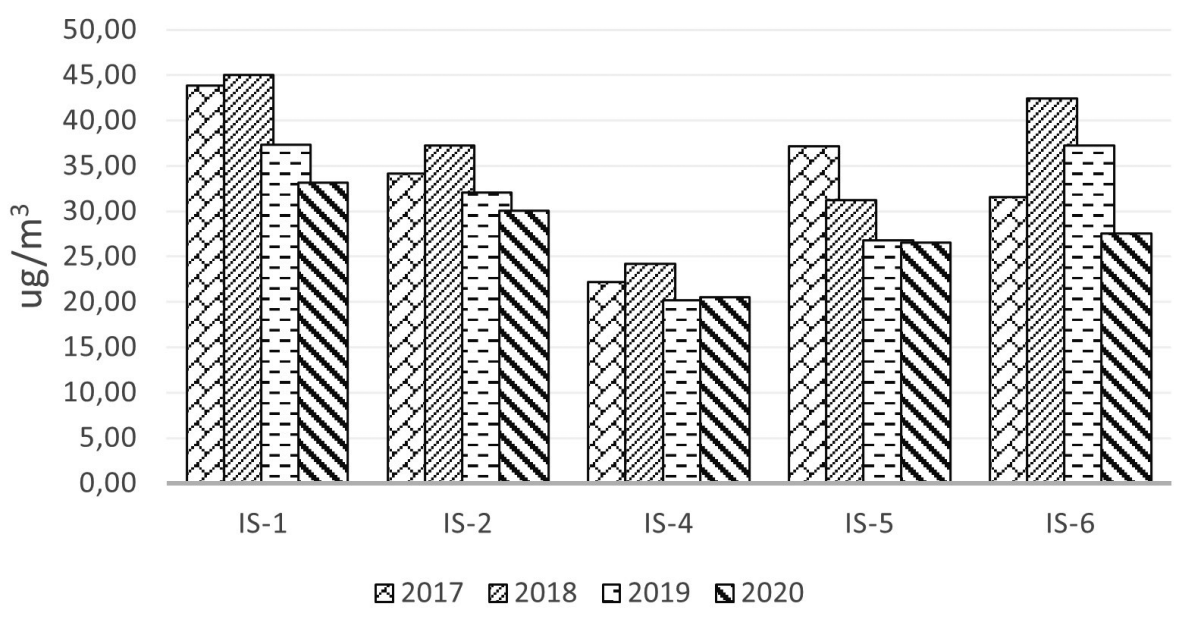

Figure 3. Annually $\mathrm{PM}_{10}$ concentrations recorded by the station in Iași, Romania.

exceedances of the daily limit values more than 35 times in a calendar year, they were registered at 8 stations, out of which 2 were at lași: 83 exceedances at IS-1 (traffic station) and 40 exceedances at IS-2 (urban background station) (28).

\section{Conclusions}

Being a risk factor for many diseases such as cardiovascular diseases and respiratory diseases, air pollution is a threat to public health. $\mathrm{PM}_{10}$ is one of the six pollutants reported by WHO to have a harmful effect on health. It is linked to a variety of severe diseases such as silicosis, lung cancer, cardiovascular disease and COPD.

The evaluation of the ambient air quality in Romania is performed by 148 automatic stations that are part of the National Network of Air Quality Monitoring (RNMCA), which is distributed throughout the country. In lași County, the monitorisation of the air quality is done by an automatic air quality monitoring network consisting of six automatic monitoring stations. According to the reports of the ANPM 
in Romania, the city of lași is one of the most polluted cities in Romania. Even though the annual concentrations of $\mathrm{PM}_{10}$ in the last two years have not exceeded the permitted concentrations, there have been more than 35 daily exceedances during the year, and these were recorded mostly in lași.

The sources of pollution are multiple and it is necessary to implement methods to reduce air pollution both nationally and globally. Future studies are needed to bring out the impact that different pollutants have on overall health and respiratory health, given that the respiratory system is the main gateway for pollutants to enter the body. A priority for global health should be the implementation of appropriate interventions established by conventions and protocols for the prevention and control of air pollution. Several environmental and social policies need to be implemented to reduce impact and minimise the risks associated with exposure to air pollutants.

\section{Conflicts of interest}

The authors have no conflicts of interest.

\section{References}

1. Heinrich J, Schikowski T. COPD patients as vulnerable subpopulation for exposure to ambient air pollution. Current Environmental Health Reports. 2018;5: 70-76. Available from: doi:10.1007/ s40572-018-0178-z.

2. WHO. Air Pollution. WHO. Available online at http://www.who.int/ airpollution/en/(accessed October 5, 2020).

3. Almetwally AA, Bin-Jumah M, Allam AA. Ambient air pollution and its influence on human health and welfare: An overview. Environmental Science and Pollution Research. 2020;27: 2481524830. Available from: doi:10.1007/s11356-020-09042-2.

4. Mukherjee A. Perspectives of the silent majority: Air pollution, livelihood, and food security. Ashgate Publishing Limited, 2002, Hampshire, England.

5. Ghorani-Azam A, Riahi-Zanjani B, Balali-Mood M. Effects of air pollution on human health and practical measures for prevention in Iran. Journal of research in medical sciences. 2016;21: 65. Available from: doi:10.4103/1735-1995.189646.

6. Han B, Hu LW, Bai Z. Human exposure assessment for air pollution. Advances in Experimental Medicine and Biology. 2017;1017: 27-57. Available from: doi:10.1007/978-981-105657-4_3.

7. Davis DL, Bell ML, Fletcher T. A look back at the London smog of 1952 and the half-century since. Environmental Health Perspectives 2002;110: A734-A735.
8. World Health Organization. World Health Statistics, Monitoring Health for the Sustainable Development Goals; 2016. http:// www.who.int/gho/publications/world_health_statistics/en/.

9. Manisalidis I, Stavropoulou E, Stavropoulos A, Bezirtzoglou E. Environmental and health impacts of air pollution: A review. Frontiers in Public Health 2020;8: 14. Available from: doi:10.3389/ fpubh.2020.00014.

10. Global initiative for chronic obstructive lung disease. Pocket Guide to COPD Diagnosis, Management, and Prevention A Guide for Health Care Professionals. 2020 Edition.

11. Fanny WS, David SC. Air pollution and chronic obstructive pulmonary disease. Respirology. 2012;17: 395-401.

12. Li J, Sun S, Tang R, Qiu H, Huang Q, Mason TG, et al. Major air pollutants and risk of COPD exacerbations: A systematic review and meta-analysis. International Journal of Chronic Obstructive Pulmonary Disease. 2016;11: 3079-3091.

13. Chapman KR, Mannino DM, Soriano JB, Vermeire PA, Buist AS, Thun MJ, et al. Epidemiology and costs of chronic obstructive pulmonary disease. European Respiratory Journal. 2006;27: 188-207.

14. Hendryx M, Luo J, Chojenta C, Byles EJ. Air pollution exposures from multiple point sources and risk of incident chronic obstructive pulmonary disease (COPD) and asthma. Environmental Research. 2019;179(A): 108783. Available from: doi:10.1016/j. envres.2019.108783.

15. Wilson WE, Suh HH. Fine particles and coarse particles: Concentration relationships relevant to epidemiologic studies. Journal of the Air \& Waste Management Association. 1997;47: 1238-1249. Available from: doi:10.1080/10473289.1997.10464074.

16. Jaafari J, Naddafi K, Yunesian M, Nabizadeh R, Hassanvand MS, Ghozikali MG, et al. Characterization, risk assessment and potential source identification of PM10 in Tehran. Microchemical Journal. 2020;154: 104533. Available from: doi:10.1016/j. microc.2019.104533.

17. Guarieiro LL, de Souza AF, Torres EA, de Andrade JB. Emission profile of 18 carbonyl compounds, $\mathrm{CO}, \mathrm{CO} 2$, and NOx emitted by a diesel engine fuelled with diesel and ternary blends containing diesel, ethanol and biodiesel or vegetable oils. Atmospheric Environment. 2009;43(17): 2754-2761. Available from: doi:10.1016/j.atmosenv.2009.02.036.

18. Hsieh NH, Liao CM. Assessing exposure risk for dust storm eventsassociated lung function decrement in asthmatics and implications for control. Atmospheric Environment 2013;68: 256-264.

19. Yan L, Wang WC, Lung SC, Sun Z, Chen C, Chen JK, et al. Polycyclic aromatic hydrocarbons are associated with increased risk of chronic obstructive pulmonary disease during haze events in China. Science of the Total Environment. 2017;574: 1649-1658.

20. Bloemsma LD, Hoek G, Smit LA. Panel studies of air pollution in patients with COPD: Systematic review and meta-analysis. Environmental Research. 2016;151: 458-468. Available from: doi:10.1016/j.envres.2016.08.018. 
21. Yin G, Liu C, Hao L, Chen Y, Wang W, Huo J, et al. Associations between size-fractionated particle number concentrations and COPD mortality in Shanghai, China. Atmospheric Environment. 2019;214: 116875. Available from: doi:10.1016/j.atmosenv.2019.116875

22. Lu F, Xu D, Cheng Y, Dong S, Guo C, Jiang X, et al. Systematic review and meta-analysis of the adverse health effects of ambient PM2.5 and PM10 pollution in the Chinese population. Environmental Research. 2015;136: 196-204. Available from: doi:10.1016/j. envres.2014.06.029.

23. IaşiCountyAirQualityMonitoringNetwork.Availableonlineat:http:// www.anpm.ro/ro/web/apm-iasi/reteaua-nationala-de-monitorizare-a-calitatii-aerului/-/asset_publisher/MCtW0ySppoYG/content/ reteaua-nationala-de-monitorizare-a-calitatii-aerului?_101_INSTANCE_MCtW0ySppoYG_redirect=http $\% 3 A \% 2 F \% 2 F w w w$. anpm.ro\%2Fro\%2Fweb\%2Fapm-iasi $\% 2$ Freteaua-nationalade-monitorizare-a-calitatii-aerului\%3Fp_p_id\%3D101_INSTANCE_MCtW0ySppoYG\%26p_p_lifecycle\%3D0\%26p_p_ state\%3Dnormal\%26p_p_mode $\% 3$ Dview $\% 26 p \_p \_c o l$ id\%3Dcolumn-2\%26p_p_col_count\%3D1\&redirect=http $\% 3 A \%$ 2F\%2Fwww.anpm.ro\%2Fro\%2Fweb\%2Fapm-iasi\%2Freteauanationala-de-monitorizare-a-calitatii-aerului\%3Fp_p_ id\%3D101_INSTANCE_MCtW0ySppoYG\%26p_p_
lifecycle\%3D0\%26p_p_state $\% 3$ Dnormal\%26p_p_ mode\%3Dview\%26p_p_col_id\%3Dcolumn-2\%26p_p_col_ count\%3D1 Accessed 20 October 2020.

24. LAW no. 104 of June 15, 2011 on ambient air quality. Available online at: https://www.calitateaer.ro/export/sites/default/. galleries/Legislation/national/Lege-nr.-104_2011-calitatea-aerului-inconjurator.pdf_2063068895.pdf Accessed 20 November 2020.

25. Romania - Air pollution country fact sheet. https://www.eea.europa.eu/themes/air/country-fact-sheets/2019-country-fact-sheets/ romania Accessed 20 November 2020

26. Report On Air Quality In Romania In 2019. http://www.anpm.ro/ documents/12220/2723600/Raport+calitatea+aerului+in+Roma nia+in+2019. pdf/36098365-2646-4af1-a426-afa6f8a264c1 Accessed 20 November 2020.

27. Report On Air Quality In Romania In 2018. http://www.anpm.ro/ documents/12220/2723600/Raport+calitatea+aerului+in+Roma nia+in+2018.pdf/dbb627ed-a6a8-44e2-a1d7-0523f1042711 Accessed 20 November 2020.

28. Report On Air Quality In Romania In 2017. http://www.anpm. ro/documents/12220/2723600/Raport+calitatea+aerului+in+ Romania+in+2017.pdf/83134206-b1d4-47ef-83d14e9e2e2e8282 Accessed 20 November 2020. 